\title{
СУЧАСНІ ТЕХНОЛОГІЇ У ВИКЛАДАННІ ДИСЦИПЛІНИ «ДИТЯЧІ ІНФЕКЦИЙНІ ХВОРОБИ» У ЗАКЛАДАХ ВИЩОЇ ОСВІТИ
}

\author{
O. A. Dralova, O. V. Usachova, O. V. Konakova \\ Zaporizhzhia State Medical University \\ MODERN TECHNOLOGIES IN TEACHING THE DISCIPLINE \\ “PEDIATRIC INFECTIOUS DISEASES” IN INSTITUTIONS OF HIGHER \\ EDUCATION
}

\begin{abstract}
Анотація. У статті висвітлено сучасні технології у викладанні дисципліни «Дитячі інфекційні хвороби» у закладах вищої освіти. Ці технології успішно впроваджені та використовуються на високому рівні викладачами кафедри.

Пандемія Covid-19 внесла свої корективи в освітній процес у всьому світі. Цей виклик прийняв і Запорізький державний медичний університет. Серед сучасних технологій, що впроваджені в освітній процес, слід виділити впровадження оn-line навчання на платформі Microsoft Office 365, а саме Microsoft Teams, електронний портал, створення сторінки кафедри у SharePoint та впровадження програми для роботи із віртуальним пацієнтом Body Interact. Ці програми мають на меті адаптувати навчальний процес до сучасних умов, навчити студентів бути модерновими, цілеспрямованими, мотивованими та креативними. Дистанційне навчання, за допомогою цих технологій, стає більш зручним, професійним.

Електронна сторінка кафедри у SharePoint дозволяє модератору кафедри наповнити актуальною інформацією, що містить всі навчальні матеріали та розклад, відповідні до факультету та курсу студентів, що вивчають дисципліну на кафедрі, трьома мовами: українською, англійською та російською.

Робота з віртуальним пацієнтом, за допомогою програми Body Interact, дає можливість студентам оволодіти навичками надання невідкладної допомоги пацієнту: стабілізувати його загальний стан, призначити необхідне обстеження та лікування, що $€$ необхідною компетентністю кожного лікаря.

Отже, використання сучасних технологій у викладанні дисципліни «Дитячі інфекційні хвороби» є безумовним перспективним напрямком навчання у закладах вищої освіти. Це дає змогу підготувати висококваліфікованих фахівців високого європейського рівня.
\end{abstract}

Ключові слова: сучасні технології; дитячі інфекційні хвороби; заклад вищої освіти.

Abstract. The article describes modern technologies in teaching the discipline "Pediatric Infectious Diseases” in universities. These technologies have been successfully implemented and used at a high level by teachers of the department.

The Covid-19 pandemic has made adjustments to the educational process around the world. Zaporizhzhia State Medical University also accepted this challenge. Among the modern technologies introduced into the educational process are the introduction of on-line training on the Microsoft Office 365 platform, namely Microsoft Teams, e-portal, creation of a department page in SharePoint and the introduction of a program to work with a virtual patient Body Interact. These programs aim to adapt the learning process to modern conditions, to teach students to be modern, focused, motivated and creative. Distance learning, with the help of these technologies, becomes more convenient, professional.

The department's website in SharePoint allows the moderator of the department to fill in relevant information that contains all teaching materials and schedule relevant to the faculty and course of students studying the discipline at the department in three languages: Ukrainian, English and Russian.

Working with a virtual patient, using the Body Interact program, gives students the opportunity to master the skills of emergency care: to stabilize his general condition, to appoint the necessary examination and treatment, which is the necessary competence of each doctor.

() О. А. Дралова, О. В. Усачова, О. В. Конакова 
Thus, the use of modern technologies in the teaching of the discipline "Pediatric Infectious Diseases" is an unconditional promising area of study at the university. This makes it possible to train highly qualified specialists of high European level.

Key words: modern technologies; pediatric infectious diseases; institution of higher education.

Вступ. Сьогодні, в епоху змін, управління освітою потребує вміння швидко реагувати на виклики, уміння бути в тренді, а також стратегічно і критично мислити. Дедалі більшого поширення набувають використання технологій дистанційного навчання в освітньому процесі різних типів закладів освіти [3]. Дистанційна освіта має особистісно-орієнтований характер. Тому дуже важливими методами навчання активно виступають навчання у співробітництві, креативне навчання та інші, що будуть спонукати студентів до пошуку знань, наполегливої творчої роботи та розвитку критичного мислення. В цьому допомагають комп’ютерні технології та Інтернет, які дуже трансформують освітнє середовище, відкриваючи доступ до найрізноманітнішої інформації та знання у всесвітній мережі [1]. Останнім часом в Україні відбуваються зміни в системі освіти, що, насамперед, пов'язано з реформуванням освіти у напрямку євроінтеграції. Тому викладачі постають перед необхідністю пошуку сучасних напрямків викладання предмета у вищій школі. Протидія таким викликам може бути реалізована за допомогою комп’ютерних технологій із застосуванням різних програм [5]. Адже сучасний викладач повинен бути також конкурентоспроможним, прогресивним та майстерним педагогом [2], повинен допомогти майбутнім лікарям чітко висловлювати свої думки, навчити вміння бачити міжпредметні зв'язки з іншими дисциплінами [6].

Мета статті - обгрунтувати сучасний рівень викладання дисципліни «Дитячі інфекційні хвороби» у Запорізькому державному медичному університеті із застосуванням новітніх технологій.

Теоретична частина. Пандемія, що спричинена Covid-19, внесла суттєві корективи до суспільного життя та освіти зокрема. Це також серйозний виклик не тільки всесвітній медицині, а й навчанню студентів у вищих медичних закладах освіти. Викладання дисципліни «Дитячі інфекційні хвороби» також потребувало вдосконалення й адаптації до нових умов та викликів. Навчальний процес у медичних ЗВО сьогодні вимагає від викладачів сучасної підготовки, якісного викладання дисципліни та сміливого креативного мислення. Сьогодні це вже складно уявити без впровадження у навчання сучасних технологій, програм, гаджетів, які значно прискорюють процес навчання та роблять його сучасним, а в умовах пандемії Covid-19 ще й необхідним.

У Запорізькому державному медичному університеті на кафедрі дитячих інфекційних хвороб активно впроваджуються та використовуються сучасні комп’ютерні технології та програми у навчальному процесі. Це дозволяє викладачам проводити заняття більш креативно, якісно та сучасно. Серед інноваційних технологій, що використовуються, слід виділити: впровадження on-line навчання на платформі Microsoft Office 365, а саме Microsoft Teams, електронний портал, створення сторінки кафедри у SharePoint та впровадження програми для роботи із віртуальним пацієнтом Body Interact. Це робить навчання у 3 ВО простим, зручним та сучасним, а також дозволяє студентам із будь-яких гаджетів вивчати дисципліну, оскільки є також мобільні версії цих програм.

Оскільки пандемія, що спричинена Covid-19, зробила неможливим звичне навчання студентів в аудиторіях 3 ВО та клінічних базах, викладання практичних занять та проведення лекцій сьогодні відбуваються на платформі Microsoft Office 365, а саме у Microsoft Teams. Впровадження цієї платформи у викладання дисципліни допомогло швидко перейти на змішану форму навчання.

Перед початком роботи з електронним порталом викладачі кафедри пройшли навчання, що гарантувало чітку та правильну роботу з цим хмарним простором. За кожною кафедрою був закріплений координатор, який допомагав у вирішенні технічних питань. Відповідальні викладачі кафедри своєчасно наповнюють та оновлюють електронний портал кафедри, який є надійним помічником для студентів 5 і 6 курсів медичних та міжнародних факультетів. Він є дуже зручним, оскільки на ньому викладена інформація трьома мовами: українською, російською та англійською. На електронному порталі представлена інформація про кафедру, розклад практичних занять, лекцій, підсумкових модульних контролів для кожної групи, тематичний план (практичних та самостійних занять, лекцій), методичні рекомендації згідно з навчальним планом, рекомендована література, інформація про наукову, лікувальну, міжнародну діяльність, роботу студентського наукового товариства, а також щомісяця оновлюється інформація щодо академічної 
заборгованості студентів по кафедрі дитячих інфекційних хвороб.

При роботі з Microsoft Teams кожний викладач, згідно з розкладом, створює групу у своєму робочому акаунті, прикріплює всіх студентів за списком, а також до власників кожної групи додає завідувача кафедри, представників деканату відповідного факультету та супровід і технічну підтримку програмного забезпечення університету. Це дає змогу «прозоро» викладати дисципліну, адекватно й об'єктивно оцінювати кожного студента та можливість доєднатися до заняття будь-кого із власників групи. Ця платформа дає можливість провести практичні заняття, для чого створюється зібрання, всім учасникам приходить сповіщення про це зібрання, і студенти мають змогу бачити, хто є організатором зібрання та о котрій годині воно розпочалося. Сьогодні це досить прогресивна платформа для викладання та спілкування зі студентами, оскільки має багато технічних переваг, таких, як: достатня швидкість підключення всіх учасників зібрання, можливість працювати з включеною камерою, що дозволяє бачити одночасно всіх студентів. Викладач має змогу, якщо потрібно, вмикати трансляцію свого екрана для більш детального пояснення навчального матеріалу, а також застосовувати «дошку» для наочної демонстрації складних для розуміння студентів моментів патогенезу чи діагностики будь-якого захворювання. Також ми маємо можливість створювати тестові та письмові завдання за допомогою Forms цієї ж платформи. Це дуже зручно для кожного викладача, оскільки ми маємо змогу встановити час початку та закінчення виконання завдання, вибрати, для кого ми призначаємо завдання (для всієї групи або окремих студентів). Крім того, після закінчення часу автоматично формується електронний журнал оцінювання кожного студента в групі. Проте ми розуміємо, що під час виконання тестових завдань ми не маємо змоги контролювати, чи використовують студенти додаткові навчальні матеріали для їх вирішення, що безумовно викликає труднощі в об’єктивному оцінюванні студентів.

Також за допомогою Microsoft Teams ми маємо змогу викладати лекційний матеріал із одночасними візуалізаціями лектора та презентації лекції для одного або декілька потоків студентів. Це робить читання лекції більш сучасним, доступним, оскільки будь-який студент може брати участь в обговоренні лекції та ставити питання лектору безпосередньо наживо та в чаті. Також цей підхід налаштовує кожного учасника на живе спілкування. В подальшому всі лекції, що викладаються на кафедрі, записуються та вивантажуються у загальний чат потоку студентів, для яких проводилися ці лекції. Це робить навчання дещо простим, тому що кожний студент має доступ до сучасного та оновленого лекційного матеріалу, та в будь-який момент може повернутися до більш ретельного засвоєння матеріалу.

Проведення державної атестації випускників також потребувало модернізації та адаптації до сучасних умов. Так, у Запорізькому державному медичному університеті проведення іспитів стало можливим також за допомогою Microsoft Teams. Була створена серед викладачів команда відповідальних за іспит модераторів, які одночасно мають змогу додавати та «відкривати» завдання для кількох потоків студентів. Проте реалізація проведення іспитів у режимі online потребує дуже кропіткої праці, бо неймовірно відповідальна технічна задача стоїть перед кожним модератором, який створює та прикріплює завдання для кожної станції на іспиті. Але слід зазначити, що саме під час такої відповідальної роботі в команді викладачів прослідковуються дуже висока чіткість, точність та професійність, а також вміння опановувати новітні технології та працювати у великій команді, бо саме в цей час кожний модератор, який виконує свою частину роботи, забезпечує реалізацію такої великої кампанії, як випускна. Це також характеризує кожного викладача як наполегливого, амбіційного, креативного та професійно розвиненого науковця, оскільки для того, щоб навчити студента користуватися новітніми технологіями, кожний викладач спочатку самостійно опановує всі можливості online платформ.

Нам також цікава думка кожного студента щодо викладача, що викладає дисципліну, та якості викладання. Для цього ми запровадили анонімне анкетування для висловлювання думки майбутніх лікарів про викладача, що проводив заняття, а також професійності та якості представлення лекційного матеріалу лектором. Аналіз цього анкетування дозволяє нам мати зворотний зв'язок від студентів, допомагає нам побачити нашу роботу очима наших учнів, мотивує та стимулює до безперервного навчання та саморозвитку. Анонімне анкетування дозволяє студентам брати активну участь у житті університету, висловлювати свою чітку позицію, вносити пропозиції у процес навчання. В анкетуванні ми обов'язковим пунктом додали питання 
щодо академічної доброчесності, нам дуже важлива думка наших студентів стосовно цього питання. Анонімне анкетування щодо академічної доброчесності також широко використовується не тільки на кафедрі дитячих інфекційних хвороб, а й на всіх кафедрах Запорізького державного медичного університету.

Одним із перспективних інновацій є створення та розроблення сторінки кафедри у SharePoint. Ця сучасна інновація дозволяє модератору кафедри наповнити актуальною інформацією, що містить всі навчальні матеріали та розклад, відповідні до факультету та курсу студентів, що вивчають дисципліну на кафедрі, трьома мовами: українською, англійською та російською. Це більш модернова версія електронного порталу, яка має значні переваги. Це, насамперед, зручність пошуку інформації, оскільки раніше студентам доводилося на порталі шукати інформацію про заняття, натискаючи на папки, які не завжди зручно відкривалися на мобільному пристрої, що робило підготовку до занять не дуже швидкою та зручною. Проте сьогодні нова сторінка у SharePoint дозволяє дуже швидко переходити за відповідними посиланнями, в яких одразу відкривається весь доступний матеріал для кожного студента. Також цей матеріал не плутає студентів, бо він однаково виглядає як на операційній системі Android, так i iOS, що зменшує час для адаптації матеріалу на екрані. Але, на нашу думку, головною перевагою розробленої сторінки y SharePoint, безумовно, є якість та рівень викладеного матеріалу. Окрім навчального матеріалу, на сторінці представлена оновлена сучасна інформація про різні види робіт кафедри, яка включає лікувальну, наукову, виховну, а також міжнародну співпрацю. Ця інформація доповнена фотографіями, схемами, зображеннями. Обов’язковою є сучасна загальна інформація про кафедру, про склад викладачів, що містить актуальну інформацію щодо професійного розвитку кожного викладача та фото. Схематично представлено розташування кафедри та схему проїзду. Ця інформація є необхідною, особливо в умовах дистанційного навчання. Тобто ця сторінка має презентабельний, модерновий та європейський вигляд.

Ще одним сучасним досягненням Запорізького державного медичного університету є можливість роботи студента із віртуальним пацієнтом за допомогою програми Body Interact. У 2018 р. на базі ЗДМУ був створений міжкафедральний тренінговий центр для підготовки лікарів-інтернів та сту- дентів. Крім того, з'явилася можливість вийти на новий більш якісний рівень оволодіння практичними навичками завдяки впровадженню в освітній процес інноваційної інтерактивної панелі - віртуального симулятора пацієнта Body Interact, який використовують провідні 3ВО медичної освіти Європи [4, 7]. 32021 р. ця програма стала доступною і для студентів. Тренування можуть відбуватись як у комп’ютерних класах університету разом із викладачами, так і самостійно вдома. Студенти 5, 6 курсів 1 та 2 медичних факультетів, міжнародного факультету мають змогу віртуально надати невідкладну допомогу пацієнту, стабілізувати його загальний стан, призначити необхідне обстеження. Програма для нашої дисципліни включає 4 сценаpiї, які охоплюють найбільш поширені невідкладні стани в клініці дитячих інфекційних хвороб, а саме: інфекційно-токсиновий шок при менінгококцемії, гострий стенозуючий ларингіт при парагрипі, ексикоз при гострих кишкових інфекціях та менінгоенцефаліт при вітряній віспі. Ці симуляційні задачі створюють віртуальні умови майбутнім лікарям для вчасної орієнтації із правильною постановкою діагнозу, у віртуальному часі «розпитати» батьків про стан дитини, провести необхідний загальний огляд по системах, призначити лабораторне обстеження. Але головною метою програми є навчити молодого спеціаліста надавати швидко та професійно невідкладну допомогу пацієнту. Оскільки в реальному житті лікар повинен швидко зорієнтуватися в клінічній ситуації, не розгубитися, бо від цього залежить безпосередньо життя пацієнта, тому програма є важливим тренінговим варіантом. Ще однією перевагою Body Interact $є$ те, що назви лікарських засобів написані латиною, що, безумовно, спонукає молодого фахівця до вдосконалення своїх знань. Студенти мають можливість надавати допомогу віртуальному пацієнту декілька разів; при невдалій спробі майбутній лікар повинен надати першу медичну допомогу та провести необхідні реанімаційні заходи. Ці «пацієнти» імітують всю клінічну картину сценарію та навіть зупинку серця, тому студенти можуть чути, як дихає хворий, його серцеву діяльність тощо. Програма максимально адаптована до реальної ситуації надання допомоги пацієнту. Дуже важливим та сучасним, на наш погляд, $є$ і те, що студент, який має логін та пароль для входу у цю програму, має можливість тренуватися і у вільний час, оскільки можна скачати додаток на мобільний телефон. Важливим $є$ те, що викладач може коментувати дію кожного 
студента під час надання допомоги «віртуальному пацієнту». Найчастішою помилкою студентів є неправильне визначення алгоритму дій. Так, програма надає обмежений час для надання допомоги, а зазвичай студенти починають із з’ясування анамнезу хворого та обстеження, як фізикального, так і лабораторного, і втрачають важливий час для надання допомоги. Тому викладачі, які працюють зі студентами в цей час, роблять акцент на пріоритетності швидких рішень, щодо допомоги хворому, а потім вже проводити огляд. Слід урахувати те, що програма, як і мобільний додаток, вимагають достатніх об’єму пам’яті та потужностей від гаджетів, проте ці моменти враховані розробниками сучасної комп’ютерної техніки та мобільних телефонів.

Висновки та перспективи подальших досліджень. Використання сучасних технологій у викладанні дисципліни «Дитячі інфекційні хвороби» $\epsilon$ безумовним перспективним напрямком навчання у ЗВО. Це робить складний процес навчання більш цікавим, а отже, й легким. Враховуючи зростаючий рівень новітніх технологій в Україні та світі,

\section{Список літератури}

1. Абакумова О. О. Дистанційна освіта: новий характер освітньої взаємодії / О. О. Абакумова // Соціально-гуманітарні дослідження та інноваційна освітня діяльність: матеріали Міжнар. наук. конф., 24-25 трав. 2019 р., Дніпро. - Дніпро, 2019. - С. 179-181.

2. Беляєва О. М. Розвиток педагогічної майстерності викладачів вищих медичних навчальних закладів: проблеми і шляхи розв’язання / О. М. Беляєва // Pedagogy and Psychology. - 2018. - VI (63), Issue: 153. - P. 15-19.

3. Бутурліна О. В. Філософсько-освітня рефлексія проблем впровадження дистанційного навчання / О. В. Бутурліна // Неперервна освіта для сталого розвитку: філософсько-теоретичні контексти та педагогічна практика : матеріали III Всеукр. наук.-практ. конф., 4 груд. 2020 р., Дніпро, КЗВО «ДАНО» ДОР. - Дніпро, 2020. - С. 10-13.

4. Впровадження проблемно-орієнтованого навчання з використанням віртуальних пацієнтів на післядипломному етапі освіти / Д. А. Задирака, Ю. Ю. Рябоконь,

\section{References}

1. Abakumova, O.O. (2019). Dystantsiina osvita: novyi kharakter osvitnoi vzaiemodii [Distance education: a new nature of educational interaction]. Sotsialno-humanitarni doslidzhennia ta innovatsiina osvitnia diialnist. Materialy Mizhnarodnoi naukovoi konferentsii - Proceedings of the International Scientific Conference Social Sciences and Humanities Research and Innovative Educational Activities. Dnipro [in Ukrainian]. що застосовуються в медицині, майбутнім лікарям дуже важливо опанувати сучасні технології ще під час навчання у медичному ЗВО. Це дасть нам перспективу, у майбутньому, більш ефективно запроваджувати сучасні комп’ютерні програми в роботі та спілкуванні з передовими медичними закладами високого європейського рівня, а також підготувати більш креативних, сміливих та високопрофесійних лікарів, що безумовно буде спонукати молодих спеціалістів для подальшого навчання та вдосконалення своїх навичок. Подальша перспективність новітніх технологій, що застосовуються у сучасному навчальному процесі, не викликає сумнівів, оскільки сучасна медицина постійно залучає у свою роботу нові комп’ютерні обладнання та програми, що дозволяє Україні щорічно навчати та випускати молодих спеціалістів високого рівня, які можуть скласти конкуренцію не тільки в нашій країні, а й у багатьох інших європейських країнах. Тому складно недооцінити роль сучасних технологій у викладанні дисципліни «Дитячі інфекційні хвороби» у Запорізькому державному медичному університеті.

О. В. Рябоконь, К. Б. Романова // Актуальні питання дистанційної освіти : Всеукр. наук.-метод. відеоконф. 3 міжнар. участю, 19-20 листоп. 2020 р., Запоріжжя. Запоріжжя, 2020. - С. 102-103.

5. Дерезюк А. В. Деякі аспекти сучасної педагогіки медичної освіти / А. В. Дерезюк // Медична освіта. 2015. - № 3. - С. 26-28.

6. Лавровська А. А. Міжпредметні та інтегровані зв'язки як необхідна складова у вивченні клінічних предметів / А. А. Лавровська, Т. В. Лапінська // Магістр медсестринства. - 2018. - № 1 (19). - С. 41-44.

7. Avramenko M. O. Results of implementation of D-PBL with virtual patients in the frames of TAME: training against medical errors project realization in surgery / M. O. Avramenko, O. O. Furyk, V. M. Kompaniiets // 3rd International Conference on Medical Education informatics, Leeds, UK, 6-7th September, 2018. - Leeds, UK, 2018. P. 39-40.

2. Beliaieva, O.M. (2018). Rozvytok pedahohichnoi maisternosti vykladachiv vyshchykh medychnykh navchalnykh zakladiv: problemy i shliakhy rozviazannia [Development of pedagogical excellence in teacher's of higher medical educational establishments: problems and solutions]. Pedagogy and Psychology, VI (63) (153) 15-19 [in Ukrainian].

3. Buturlina, O.V. (2020). Filosofsko-osvitnia refleksiia problem vprovadzhennia dystantsiinoho navchannia 
[Philosophical and educational reflection on the problems of implementing distance learning]. Neperervna osvita dlia staloho rozvytku: filosofsko-teoretychni konteksty ta pedahohichna praktyka: Materialy III Vseukrainskoi naukovo-praktychnoi konferentsii - Continuing education for sustainable development: philosophical and theoretical contexts and pedagogical practice: Proceedings of the III All-Ukrainian scientific-practical conference. Dnipro: KZVO «DANO» DOR [in Ukrainian].

4. Zadyraka, D.A., Riabokon, Yu.Yu., Riabokon, O.V., \& Romanova, K.B. (2020). Vprovadzhennia problemnooriientovanoho navchannia z vykorystanniam virtualnykh patsiientiv na pisliadyplomnomu etapi osvity [Introduction of problem-oriented learning with the use of virtual patients at the postgraduate stage of education]. Aktualni pytannia dystantsiinoi osvity Vseukrainskoi naukovometodychnoi video konferentsii z mizhnarodnoiu uchastiu - Current issues of distance education of the All-Ukrainian scientific-methodical video conference with international participation. Zaporizhzhia [in Ukrainian].

5. Dereziuk, A.V. (2015). Deiaki aspekty suchasnoi pedahohiky medychnoi osvity [Some aspects of modern medical education pedagogy]. Medychna osvita - Medical Education, 3, 26-28 [in Ukrainian].

6. Lavrovska, A.A., \& Lapinska, T.V. (2018). Mizhpredmetni ta intehrovani zviazky yak neobkhidna skladova u vyvchenni klinichnykh predmetiv [Interdisciplinary and integrated communication as a necessary component of clinical study subjects]. Mahistr medsestrynstva - Muster of Nursing, 1(19), 41-44 [in Ukrainian].

7. Avramenko, M.O., Furyk, O. O., \& Kompaniiets, V. M. (2018). Results of implementation of D-PBL with virtual patients in the frames of TAME: training against medical errors project realization in surgery. $3^{\text {rd }}$ International Conference on Medical Education informatics. Leeds, UK. 